Gut, 1978, 19, 743-747

\title{
Prolyl hydroxylase activity in serum and rectal mucosa in inflammatory bowel disease
}

\author{
M. J. G. FARTHING, A. P. DICK ${ }^{1}$, G. HESLOP, AND C. I. LEVENE \\ From the Department of Medical Gastroenterology, Addenbrooke's Hospital, Cambridge, and the \\ Department of Pathology, University of Cambridge, Cambridge
}

SUMMARY Prolyl hydroxylase activity in rectal mucosa was found to be significantly greater in 11 patients with Crohn's disease than in 11 control subjects with the irritable bowel syndrome and 16 patients with ulcerative colitis $(P<0.005)$. Seven of the patients with Crohn's disease had a histologically normal rectum. This abnormality in apparently normal mucosa supports the concept that Crohn's disease is a 'continuous' disease of the gastrointestinal tract. Although there was no significant difference in prolyl hydroxylase activity between control subjects and patients with ulcerative colitis, those patients with quiescent disease tended to have lower values than those with active mucosal inflammation. Prolyl hydroxylase activity could not, however, be detected in the sera of either healthy control subjects or patients with inflammatory bowel disease.

The enzyme prolyl hydroxylase hydroxylates prolyl residues in developing collagen alpha chains which enables assembly of three alpha chains to form the triple helix, tropocollagen. It has been used as an indicator of collagen synthesis in many tissues and is probably a rate-limiting step in synthesis (Cardinale and Undenfriend, 1974). Hepatic prolyl hydroxylase activity has been shown to be increased before deposition of collagen in experimental hepatic fibrosis (Takeuchi and Prockop, 1969; McGee et al., 1974), in alcoholic hepatitis, chronic active hepatitis, and cirrhosis (Mezey et al., 1976; Fuller et al., 1976). One study (Stein et al., 1970) suggests that prolyl hydroxylase activity can be measured in human serum, when increased activity was found in some patients with cirrhosis, hepatitis and hepatoma.

Ileal and colonic fibrosis is frequently seen in Crohn's disease, often leading to stricture formation and intestinal obstruction (Morson and Dawson, 1972); fibrosis is not a conspicuous feature of ulcerative colitis.

In this study prolyl hydroxylase activity was measured in sera and rectal mucosal biopsies from patients with Crohn's disease and ulcerative colitis, and its value in discriminating between these conditions was examined.

\footnotetext{
${ }^{1}$ Address for reprint requests: Dr A. P. Dick, Department of Medical Gastroenterology, Addenbrooke's Hospital, Hills Road, Cambridge, CB2 2QQ.
}

Received for publication 5 February 1978

\section{Prolyl hydroxylase activity in serum}

\section{Methods}

\section{PATIENTS}

Twelve healthy control subjects (mean age 34.7 years), 10 patients with Crohn's disease (mean age 36.5 years), and 10 patients with ulcerative colitis (mean age 46.6 years) were investigated. Each group had an equal sex distribution and at the time of investigation half the patients with inflammatory bowel disease were assessed as having active disease.

Venous blood was taken in the morning from non-fasting subjects, separated in the cold, and on the same day the serum was assayed in duplicate for prolyl hydroxylase activity using a modification of the method described by Hutton et al., (1966). This is based on the stoichiometric formation of $\left[{ }^{3} \mathrm{H}\right]$ water and $\left[{ }^{3} \mathrm{H}\right]$ hydroxyproline when an underhydroxylated $3,4\left[{ }^{3} \mathrm{H}\right]$ proline substrate is incubated with enzyme and cofactors. The reaction mixture consisted of $3,4\left[{ }^{3} \mathrm{H}\right]$ proline labelled substrate $\left(3.0 \times 10^{5} \mathrm{dpm}\right), 1.0 \mathrm{ml}$ serum, made up to $2.0 \mathrm{ml}$ with $0.1 \mathrm{M}$ Tris- $\mathrm{HCl}(\mathrm{pH} \mathrm{7.4)}$ to give final concentrations of the cofactors of $0.012 \mathrm{M}$ ascorbic acid, $0.001 \mathrm{M}$ ferrous ammonium sulphate, and $0.002 \mathrm{M}$ $\alpha$-ketoglutarate. Incubations were carried out aerobically at $37^{\circ} \mathrm{C}$ and stopped after 30 minutes by addition of $0.2 \mathrm{ml} 50 \%$ trichloroacetic acid. $\left[{ }^{3} \mathrm{H}\right]$ water was separated by vacuum distillation and counted in a Beckman LS-250 scintillation 
counter after addition of $10 \mathrm{ml}$ scintillant (PCS solubiliser diluted 2:1 with xylene). Results were expressed as counts per minute per ml serum above a boiled blank.

The $\left[{ }^{3} \mathrm{H}\right]$ proline labelled substrate was prepared by incubating decapitated, minced 8-day old chick embryos with $3,4\left[{ }^{3} \mathrm{H}\right]$ proline (Amersham) in the presence of $1.0 \mathrm{mM} \alpha \alpha^{\prime}$-dipyridyl made up in a modified Krebs-Ringer solution (Hutton et al., 1966; Dehm and Prockop, 1971). The substrate was stored in $2.0 \mathrm{ml}$ aliquots at $-20^{\circ} \mathrm{C}$ and thawed before use. The same batch of substrate was used for all assays reported in this study and was dialysed against water before each assay. The ratio of proline to hydroxyproline in the substrate was determined (Bates et al., 1972) and found to be 20:1 confirming underhydroxylation. The method was validated by incubating the substrate with a colonic mucosal extract (see below) as a source of prolyl hydroxylase and the ratio of proline to hydroxyproline determined as before. After incubation the ratio was found to have fallen significantly confirming that hydroxylation had occurred in parallel with production of $\left[{ }^{3} \mathrm{H}\right] \mathrm{H}_{2} \mathrm{O}$, thus demonstrating that the measurement of $\left[{ }^{3} \mathrm{H}\right] \mathrm{H}_{2} \mathrm{O}$ reflected the presence of functional prolyl hydroxylase. A chick-embryo enzyme source (Berg and Prockop, 1973) was assayed as a routine control with each assay.

\section{Prolyl hydroxylase activity in rectal mucosa}

Methods

PATIENTS

Eleven control subjects (seven females and four males, mean age 55.1 years) with the irritable bowel syndrome, 16 patients with ulcerative colitis (nine females and seven males, mean age 51.0 years), and 11 patients with Crohn's disease (five females and six males, mean age 46.5 years) were studied. Assessment was made as to whether the patients' disease was active or quiescent, and details of their treatment were noted (Tables 1 and 2).

Two adjacent rectal mucosal biopsies $8-10 \mathrm{~cm}$ from the anal margin were taken, one for routine histological examination and a second was stored at $-20^{\circ} \mathrm{C}$ after washing in $0.1 \mathrm{M}$ Tris- $\mathrm{HCl}$ buffer (pH 7.4). Within 48 hours the biopsy was weighed wet after thawing, homogenised at $4^{\circ} \mathrm{C}$ in a PotterElvehjem apparatus with $1.2 \mathrm{ml}$ buffer composed of $0.05 \mathrm{M}$ Tris- $\mathrm{HCl}$ (pH 7.4), 0.25 M sucrose, 10-5 ethylenediamine tetraacetic acid, and $10^{-5} \mathrm{M}$ dithiothreitol (Fuller et al., 1976). Biopsies weighed $8 \cdot 0-37 \cdot 1 \mathrm{mg}$ and there were no significant differences in weight between control and patient groups. The homogenate was centrifuged $\left(4^{\circ} \mathrm{C}\right)$ for 10 minutes at $12000 \mathrm{rpm}$ and the supernatant assayed immediately by the method described for serum, as prolyl hydroxylase activity of rectal mucosal biopsies was found to fall to $50 \%$ after seven days despite storage at $-20^{\circ} \mathrm{C}$. The protein concentration of the supernatant was determined (Lowry et al., 1951) and prolyl hydroxylase activity expressed as counts per minute per milligram of protein.

\section{Results}

PROLYL HYDROXYLASE ACTIVITY IN SERUM Prolyl hydroxylase activity could not be detected in either the control sera or in sera from patients with active and quiescent inflammatory bowel disease.

Table 1 Clinical data and prolyl hydroxylase activity in rectal mucosa of patients with ulcerative colitis

\begin{tabular}{|c|c|c|c|c|c|}
\hline Patient & $\begin{array}{l}\operatorname{Age}(y r) \\
\operatorname{sex}\end{array}$ & Extent & $\begin{array}{l}\text { Inflamed } \\
\text { rectal mucosa }\end{array}$ & $\begin{array}{c}\text { Prednisone } \\
(\mathrm{mg} / 24 \mathrm{~h})\end{array}$ & $\begin{array}{l}\text { Prolyl hydroxylase } \\
\text { (cpm/mg protein) } \\
\text { activity }\end{array}$ \\
\hline 1 & $31 \mathrm{~F}$ & Extensive & - & $10 \cdot 0$ & $87 \cdot 3$ \\
\hline 2 & $86 \mathrm{M}$ & Distal & + & - & 567.2 \\
\hline 3 & $33 \mathrm{~F}$ & Left-sided & + & 10.0 & $159 \cdot 3$ \\
\hline 4 & $72 \mathrm{~F}$ & Distal & + & - & $732 \cdot 4$ \\
\hline 5 & $27 \mathrm{~F}$ & Distal & - & - & 0 \\
\hline 6 & $20 \mathrm{M}$ & Distal & - & - & $722 \cdot 6$ \\
\hline 7 & $36 \mathrm{M}$ & Extensive & + & 10.0 & 390.9 \\
\hline 8 & $67 \mathrm{M}$ & Distal & + & - & 114.0 \\
\hline 9 & $60 \mathrm{~F}$ & Extensive & + & - & 91.8 \\
\hline 10 & $51 \mathrm{~F}$ & Distal & - & - & 0 \\
\hline 11 & $58 \mathrm{~F}$ & Distal & - & - & $4 \cdot 0$ \\
\hline 12 & $59 \mathrm{M}$ & Distal & + & - & 0 \\
\hline 13 & $44 \mathrm{~F}$ & Distal & - & - & $116 \cdot 1$ \\
\hline 14 & $72 \mathrm{~F}$ & Extensive & - & - & 0 \\
\hline 15 & $53 \mathrm{M}$ & Extensive & - & - & $41 \cdot 2$ \\
\hline 16 & $47 \mathrm{M}$ & Distal & - & - & $108 \cdot 7$ \\
\hline
\end{tabular}


Table 2 Clinical data and prolyl hydroxylase activity in rectal mucosa of patients with Crohn's disease

\begin{tabular}{|c|c|c|c|c|c|c|}
\hline Patient & $\begin{array}{l}\text { Age (yr) } \\
\text { sex }\end{array}$ & $\begin{array}{l}\text { Normal } \\
\text { sigmoidoscopy }\end{array}$ & $\begin{array}{l}\text { 'Normal' } \\
\text { histology }\end{array}$ & $\begin{array}{l}\text { Prednisone } \\
(m g / 24 h)\end{array}$ & $\begin{array}{l}\text { Distal } \\
\text { extent }\end{array}$ & $\begin{array}{l}\text { Prolyl hydroxylase } \\
\text { activity } \\
\text { (cpm/mg protein) }\end{array}$ \\
\hline 1 & $28 \mathrm{M}$ & + & + & $2 \cdot 5$ & Caecum & $294 \cdot 3$ \\
\hline 2 & $55 \mathrm{~F}$ & + & + & - & $\begin{array}{l}\text { Sigmoid } \\
\text { colon }\end{array}$ & $492 \cdot 3$ \\
\hline 3 & $55 \mathrm{M}$ & - & - & - & $\begin{array}{l}\text { Transverse } \\
\text { colon }\end{array}$ & $734 \cdot 7$ \\
\hline 4 & $65 \mathrm{~F}$ & + & + & - & $\begin{array}{l}\text { Transverse } \\
\text { colon }\end{array}$ & $1705 \cdot 0$ \\
\hline 5 & $52 \mathrm{M}$ & + & + & $10 \cdot 0$ & $\begin{array}{l}\text { Descending } \\
\text { colon }\end{array}$ & $1051 \cdot 0$ \\
\hline 6 & $30 \mathrm{M}$ & + & + & $5 \cdot 0$ & $\begin{array}{l}\text { Sigmoid } \\
\text { colon }\end{array}$ & 398.9 \\
\hline 7 & $63 \mathrm{M}$ & - & - & - & Rectum & 655.8 \\
\hline 8 & $40 \mathrm{M}$ & + & + & - & $\begin{array}{l}\text { Descending } \\
\text { colon }\end{array}$ & 510.0 \\
\hline 9 & $33 \mathrm{~F}$ & - & - & - & $\begin{array}{l}\text { Ascending } \\
\text { colon }\end{array}$ & $404 \cdot 2$ \\
\hline 10 & $67 \mathrm{~F}$ & - & - & $15 \cdot 0$ & Rectum & $314 \cdot 5$ \\
\hline 11 & $24 \mathrm{~F}$ & + & + & $20 \cdot 0$ & $\begin{array}{l}\text { Sigmoid } \\
\text { colon }\end{array}$ & $258 \cdot 5$ \\
\hline
\end{tabular}

\section{PROLYL HYDROXYLASE ACTIVITY IN}

\section{RECTAL MUCOSA}

Ulcerative colitis

Prolyl hydroxylase activity in rectal mucosal biopsies from 11 control subjects with the irritable bowel syndrome (mean 190.4 \pm S E $71.9 \mathrm{cpm} / \mathrm{mg}$ protein) did not differ significantly from values obtained in 16 patients with ulcerative colitis, (mean 196.0 \pm S E $64.6 \mathrm{cpm} / \mathrm{mg}$ protein) (Fig. 1, Table 3). Patients with quiescent ulcerative colitis tended to have lower prolyl hydroxylase activity (mean $120.0 \pm \mathrm{S} \mathrm{E} 77.0 \mathrm{cpm} / \mathrm{mg}$ protein) than those with active disease (mean 293.7 \pm S E 140.0 $\mathrm{cpm} / \mathrm{mg}$ protein), although this difference was not significant. One patient with quiescent disease had a higher level of prolyl hydroxylase activity (722.6 $\mathrm{cpm} / \mathrm{mg}$ protein) than the others (Fig. 2) but it was noted that his disease had recently been active. There was no significant difference in prolyl hydroxylase activity between those patients receiving and those not receiving corticosteroid treatment.

Table 3 Prolyl hydroxylase activity in rectal mucosa of subjects and patients with inflammatory bowel disease

\begin{tabular}{lll}
\hline & & $\begin{array}{l}\text { Prolyl hydroxylase } \\
\text { activity } \\
\text { (mean } \pm S E \\
\text { cpm/mg protein) }\end{array}$ \\
\hline Controls & $(\mathrm{n}=11)$ & $\begin{array}{l}190.4 \pm 71.9 \\
\mathbf{P}<0.005\end{array}$ \\
Crohn's disease & $(\mathrm{n}=11)$ & $\begin{array}{l}620.0 \pm 129.0 \\
\mathbf{P}<0.005\end{array}$ \\
Ulcerative colitis & $(\mathrm{n}=16)$ & $196.0 \pm 64.6$ \\
\hline
\end{tabular}

\section{Crohn's disease}

Prolyl hydroxylase in rectal mucosal biopsies from 11 patients with Crohn's disease was significantly greater than both control subjects and colitics (mean $620.0 \pm$ SE $129.0 \mathrm{cpm} / \mathrm{mg}$ protein $P<$ 0.005 ) (Fig. 1). In seven of the patients the sigmoidoscopic and histological appearances of the rectum were normal, although Crohn's disease was present elsewhere in the gastrointestinal tract (Fig. 2). Prolyl hydroxylase activity in five patients receiving corticosteroid treatment tended to be lower (mean $463.4 \pm$ S E $148.7 \mathrm{cpm} / \mathrm{mg}$ protein) than in those not receiving corticosteroids (mean 750.5 \pm S E 197.0 $\mathrm{cpm} / \mathrm{mg}$ protein) but this difference was not significant.

\section{'Indeterminate' colitis}

In four patients, three females and one male (mean age 41.75 years) at the time the biopsies were taken, clinical, radiological, and histological evidence did not distinguish definitely between Crohn's disease and ulcerative colitis. Their results are included in Fig. 1.

\section{Discussion}

Prolyl hydroxylase activity could not be detected in the sera of healthy controls or in patients with either active or quiescent inflammatory bowel disease. We can find no record of a previous study of prolyl hydroxylase activity in the serum of patients with inflammatory bowel disease but Stein et al., (1970) detected activity of this enzyme in the sera of 

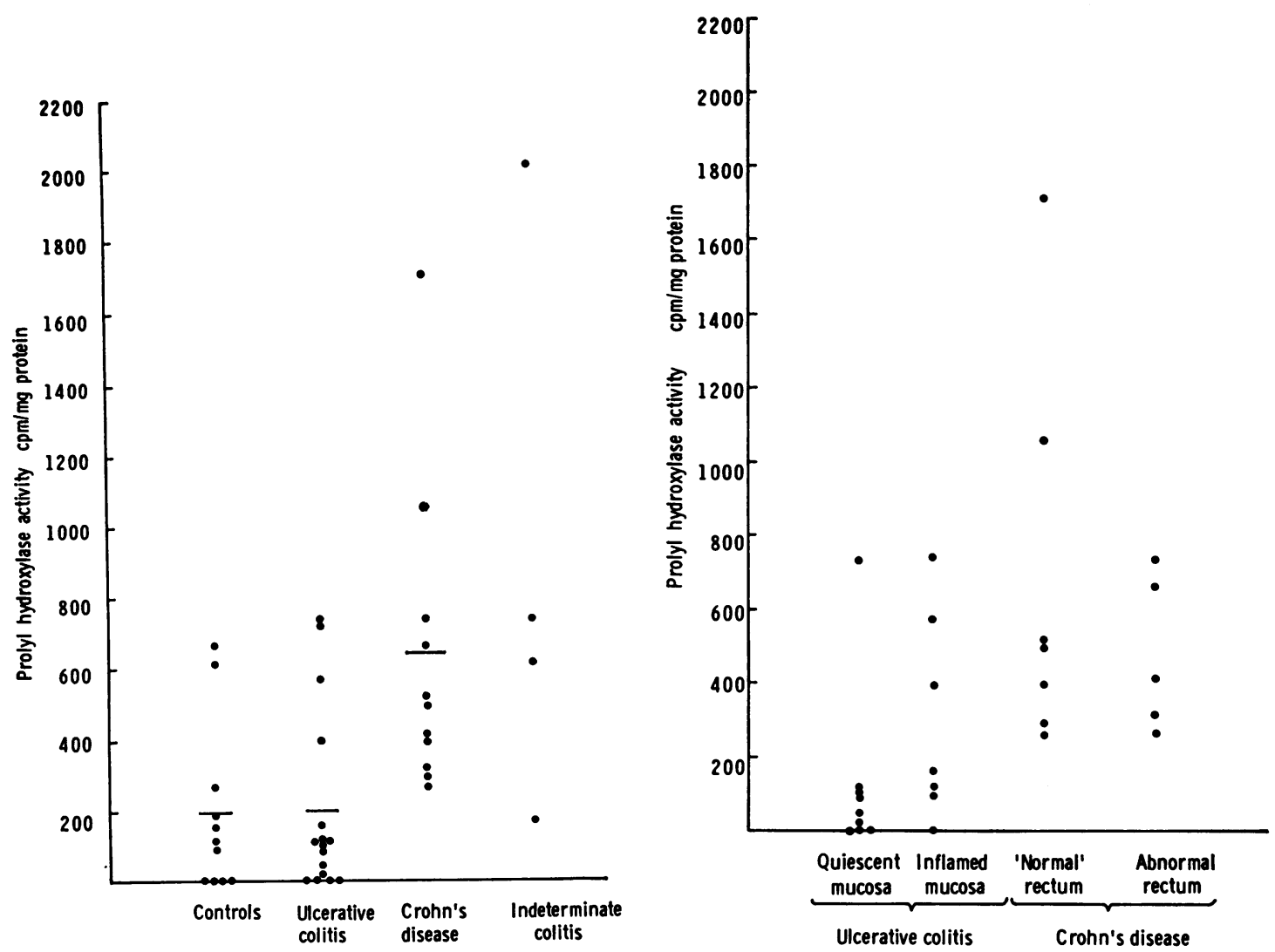

Fig. 1

Fig. 2

Figs 1 and 2 Prolyl hydroxylase activity in the rectal mucosa of patients with inflammatory bowel disease and control subjects with the irritable bowel syndrome.

healthy controls and found it raised in a variety of conditions, particularly hepatitis, cirrhosis, and hepatoma. We have also investigated patients with these hepatic disorders but were unable to confirm their findings (Farthing et al., 1977, unpublished data).

Prolyl hydroxylase activity in rectal mucosa was found to be significantly greater in Crohn's disease than either control subjects or patients with ulcerative colitis. Seven of the patients with Crohn's disease had a histologically normal rectum. This finding supports the concept that despite normal macro- and microscopic appearances, Crohn's disease is a 'continuous' disease of the gastrointestinal tract. Quantitative histology on 'normal' rectal biopsies in Crohn's disease has demonstrated significant increases in plasma cell density (Dyer et al., 1970; Goodman et al., 1976), in the volume of the lamina propria (Goodman et al., 1976), and in lymphoid content (Dyer et al., 1970). It has also been shown that there is a significant reduction in intestinal disaccharidase in jejunal biopsies from patients with Crohn's disease which was thought to be confined to the distal ileum or colon (Dunne et al., 1977). Further evidence for this hypothesis is provided by the finding that glucosamine-synthetase activity is increased in the rectal mucosa of some patients with Crohn's disease whose rectal biopsy on routine histological examination was normal (Goodman et al., 1977). Raised levels of glucosamine-synthetase were also found in patients with resolving ulcerative colitis. Estimation of prolyl hydroxylase would appear to offer a diagnostic advantage as increased activity was only found in Crohn's disease. This finding is consistent with the extensive fibrosis seen in Crohn's disease.

Although in this study there was no significant difference in prolyl hydroxylase activity between patients who had or had not received corticosteroids, there was a tendency for the activity to be lower in those on such treatment. There is evidence in rats 
that prolyl hydroxylase is decreased in many tissues after administration of triamcinolone acetate (Cutroneo et al., 1975), although other studies suggest that inhibition of collagen synthesis by glucocorticoids is independent of prolyl hydroxylase (Oikarinen, 1977).

This study provides further evidence that in Crohn's disease there are abnormalities in apparently normal mucosa.

\section{References}

Bates, C. J., Bailey, A. J., Prynne, C. J., and Levene, C. I. (1972). The effect of ascorbic acid on the synthesis of collagen precursor secreted by 3T6 mouse fibroblasts in culture. Biochimica et Biophysica Acta, 278, 372-390.

Berg, R. A., and Prockop, D. J. (1973). Affinity column purification of protocollagen proline hydroxylase from chick embryos and further characterisation of the enzyme. Journal of Biological Chemistry, 248, 1175-1182.

Cardinale, G. J., and Undenfriend, S. (1974). Prolyl hydroxylase. Advances in Enzymology, 41, 245-300.

Cutroneo, K. R., Stassen, F. L. H., and Cardinale, G. J. (1975). Anti-inflammatory steroids and collagen metabolism: glucocorticoid-mediated decrease of prolyl hydroxylase. Molecular Pharmacology, 11, 44-51.

Dehm, P., and Prockop, D. J. (1971). Synthesis and extrusion of collagen by freshly isolated cells from chick embryo tendon. Biochimica et Biophysica Acta, 240, 358-369.

Dunne, W. T., Cooke, W. T., and Allan, R. N. (1977). Enzymatic and morphometric evidence for Crohn's disease as a diffuse lesion of the gastrointestinal tract. Gut, 18, 290-294.

Dyer, N. H., Stansfeld, A. G., and Dawson, A. M. (1970).
The value of rectal biopsy in the diagnosis of Crohn's disease. Scandinavian Journal of Gastroenterology, 5, 491-496.

Fuller, G. C., Nolan, J. C., Fink, S., and Rodil, J. V. (1976). Prolyl hydroxylase activity in normal and diseased human liver. Proceedings of the Society for Experimental Biology and Medicine, 151, 61-64.

Goodman, M. J., Kent, P. W., and Truelove, S. C. (1977). Glucosamine synthetase activity of the colonic mucosa in ulcerative colitis and Crohn's disease. Gut, 18, 219-228.

Goodman, M. J., Skinner, J. M., and Truelove, S. C. (1976). Abnormalities in the apparently normal bowel mucosa in Crohn's disease. Lancet, 1, 275-278.

Hutton, J. J., Jr, Tappel, A. L., and Undenfriend, S. (1966). A rapid assay for collagen proline hydroxylase. Analytical Biochemistry, 16, 384-394.

Lowry, O. H., Rosebrough, N. J., Farr, A. L., and Randall, R. J. (1951). Protein measurement with the folin phenol reagent. Journal of Biological Chemistry, 193, 265-275.

Mezey, E., Potter, J. J., and Maddrey, W. C. (1976). Hepatic collagen proline hydroxylase activity in alcoholic liver disease. Clinica Chimica Acta, 68, 313-320.

McGee, J. O'D., Patrick, R. S., Rodger, M. C., and Luty, C. M. (1974). Collagen proline hydroxylase activity and ${ }^{35}$ S-sulphate uptake in human liver biopsies. Gut, 15, 260-267.

Morson, B. C., and Dawson, I. M. P. (1972). Gastrointestinal Pathology. Blackwell: Oxford.

Oikarinen, A. (1977). Effect of betamethasone-17-valerate on synthesis of collagen and prolyl hydroxylase activity in chick embryo tendon cells. Biochemical Pharmacology, 26, 875-879.

Stein, H. D., Keiser, H. R., and Sjoerdsma, A. (1970). Proline-hydroxylase activity in human blood. Lancet, 1, 106-109.

Takeuchi, T., and Prockop, D. J. (1969). Protocollagen proline hydroxylase in normal liver and in hepatic fibrosis. Gastroenterology, 56, 744-750. 